\title{
Consequences of intra-uterine growth retardation for postnatal growth, metabolism and pathophysiology
}

\author{
P. L. Greenwood ${ }^{1}$ and A. W. Bell ${ }^{2 *}$ \\ ${ }^{1}$ NSW Agriculture Beef Industry Centre, University of New England, Armidale, NSW 2351 , \\ Australia; and ${ }^{2}$ Department of Animal Science, 149 Morrison Hall, Cornell University, \\ Ithaca, NY 14853-4801, USA
}

Intra-uterine growth retardation (IUGR), caused by maternal undernutrition or placental insufficiency, is usually associated with disproportionately large reductions in the growth of some fetal organs and tissues (thymus, liver, spleen, thyroid) and impaired cellular development of other tissues (small intestine, secondary wool follicles, skeletal muscle). Growth of other tissues, most notably brain, is relatively unimpaired. In our recent study of postnatal consequences of IUGR in the offspring of prolific ewes, growth-retarded newborn lambs tended to be hypoglycaemic and showed sluggish postnatal engagement of the growth hormone $(\mathrm{GH})-$ insulin-like growth factor (IGF) system. When artificially reared in an optimum environment, low birth weight lambs grew at rates similar to those of normal lambs. However, low birth weight lambs were fatter at any given weight, apparently related to their high energy intakes, especially soon after birth, had low maintenance energy requirements, and limited capacity for bone and muscle growth. These growth characteristics were accompanied by higher plasma concentrations of $\mathrm{GH}$ and leptin, and lower concentrations of insulin-like growth factor I (IGF-I) during the first 2 weeks of postnatal life, and higher concentrations of insulin during subsequent growth up to $20 \mathrm{~kg}$ body weight. Emerging evidence indicates that in sheep, as in rodents, fetal programming of postnatal cardiovascular and metabolic dysfunctions is associated with IUGR and may be mediated partly by overexposure of the fetus to cortisol. Similar postnatal responses can be elicited by maternal undernutrition or cortisol treatment in early to mid-pregnancy without changing the growth of the fetus or placenta.

\section{Introduction}

A decade ago we noted the continuing validity of an earlier complaint by Everitt (1968) that the extent to which [events of later life] may be modified by factors operating during 
the intra-uterine formative stages appears to be insufficiently appreciated' (Bell, 1992). At about the same time, epidemiological evidence for the notion of 'fetal programming' began to accumulate, on the basis of the postulate that prenatal nutritional experience can have indelible influences on postnatal development and later incidence of systemic diseases in humans (Barker, 1998). Animal experiments have replicated and sought to explain mechanistically the epidemiological associations that have now been confirmed in several human populations (Langley-Evans, 2001). Much of this work has been confined to rodents but is now being extended to other species, including sheep.

This review focuses on the postnatal consequences of intra-uterine growth retardation (IUGR) in sheep. Our recent work on early postnatal metabolic development and the capacity for growth of key tissues in lambs with severe, natural IUGR is summarized. Other, recent studies on incipient or actual pathophysiological consequences of prenatal nutritional insufficiency and IUGR in neonatal and older sheep are discussed too.

\section{Natural causes and experimental models of IUGR}

\section{Maternal nutrient deprivation}

Acute effects of fasting and longer term effects of more prolonged undernutrition on patterns of fetal growth in sheep have been described in a series of studies reviewed by Mellor et al. (1983). These studies demonstrated that fetal growth is sensitive to even a few days of maternal feed deprivation and is especially responsive to maternal glycaemia. This finding is consistent with the established role of glucose as a primary source of energy for fetal growth and the known effects of maternal energy intake on glucose supply to the conceptus (Bell et al., 1999). Maternal protein deprivation, uncomplicated by energy restriction, also predictably reduces growth of sheep fetuses, despite compensatory responses in maternal tissues (McNeill et al., 1997).

\section{Placental insufficiency}

Placental mass and associated capacity for maternal-fetal nutrient transfer are powerful determinants of fetal growth during late gestation in sheep and cattle. This finding has been most persuasively demonstrated by controlled manipulation of placental size or functional capacity using pre-mating carunclectomy (Alexander, 1964), heat-induced placental stunting (Alexander and Williams, 1971) or uteroplacental vascular embolization (Creasy et al., 1972). Natural variations in fetal weight as a result of varying litter size in prolific ewes are strongly correlated with placental mass per fetus (Rhind et al., 1980; Greenwood et al., 2000a). The profound growth retardation of fetuses in overfed, primiparous ewes too has been attributed to a primary reduction in placental growth (Wallace et al., 2000).

The probably common aetiology of IUGR in experimentally induced and natural cases of placental insufficiency is illustrated by the similar patterns of association between fetal and placental weights in pregnant ewes with varying conceptus weights due to carunclectomy, heat stress, litter size and overfeeding of primiparous dams (Fig, 1). In each of these cases, severe growth retardation is associated with chronic fetal hypoxaemia and hypoglycaemia during late gestation (Harding et al, 1985; Bell et al., 1987; Wallace et al., 2002).

\section{Growth of fetal organs and tissues}

Effects of IUGR on allometric growth of individual organs and tissues vary with the severity and gestational timing of growth restriction. Nevertheless, some very consistent relationships 


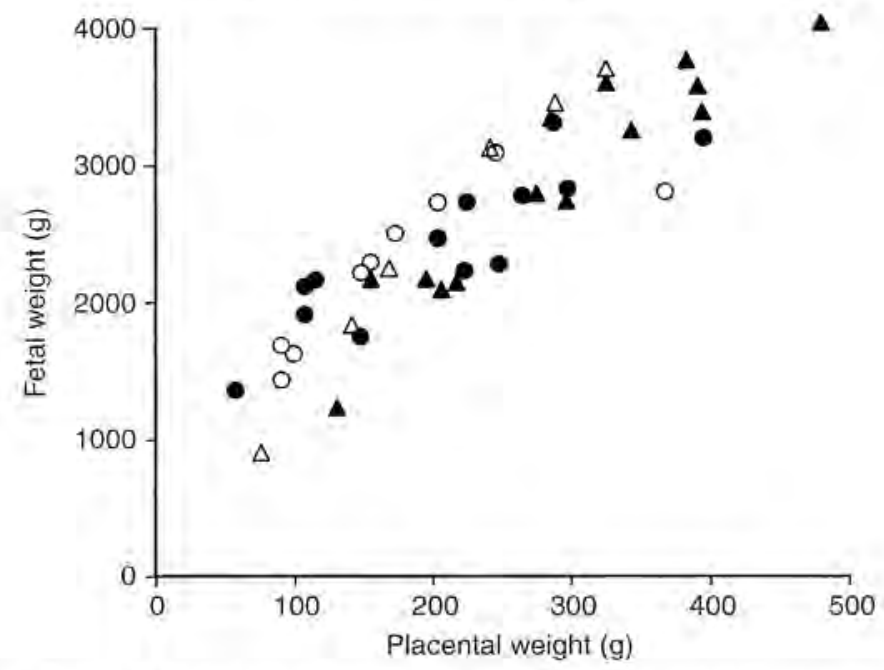

Fig. 1. Relationship between fetal and placental weights in ewes representing different models of placental insufficiency during late pregnancy. Variation in placental weight was achieved by pre-mating carunclectomy (Owens et al., 1986), chronic heat treatment (O, Bell et.al., 1987), natural variation in litter size (A; Greenwood et ál., 2000a) and overfeeding of adolescent ewes (4; Wallace et al., 2000).

between relative size of anatomical parts and birth weight are evident in Alexander's (1974) summary of data from some 250 newborn lambs with birth weights ranging from 1 to $5 \mathrm{~kg}$. These results were collected in nine series of experiments in which fetal growth was influenced by greatly differing levels of maternal nutrition, chronic maternal heat stress, carunclectomy or natural variation in litter size. In general, the IUGR-related growth penalty was disproportionately large in liver, spleen, thyroid and, most especially, thymus. The development of secondary wool follicles was also reduced disproportionately in small lambs. Conversely, growth of the brain, other head parts and the adrenal glands was relatively unimpaired in small newborn lambs. There was a tendency for alimentary tissues and the kidneys to be relatively larger, and for skeletal muscles to be somewhat smaller in relation to birth weight, whereas the masses of most bones, pulmonary and adipose tissues were proportionately related to body weight. These data are generally consistent with those of others who have examined effects of maternal undernutrition (Wallace, 1948), carunclectomy (Harding et al., 1985), placental embolization (Creasy et al., 1972), overfeeding of adolescent ewes (Wallace et al., 2000), and extreme natural variation in litter size (P. Greenwood and A. Bell, unpublished) on patterns of ovine fetal growth during late gestation.

\section{Developmental and physiological characteristics of the growth-retarded neonate}

Greenwood et al. (2002) compared plasma concentrations of metabolites and hormones in normally grown and severely growth-retarded male Suffolk $\times$ (Finnsheep $\times$ Dorset) lambs at birth and during postnatal growth to a nominal live weight of $20 \mathrm{~kg}$. Well-grown (birth weight $>4.3 \mathrm{~kg}$ ) and growth-retarded (birth weight $<2.9 \mathrm{~kg}$ ) lambs were removed from their dams at birth and reared artificially on sheep's milk replacer as described by Greenwood 
Table 1. Plasma concentrations of metabolites and hormones in normally grown and severely growth-retarded newborn lambs

\begin{tabular}{lccc}
\hline Variable & $\begin{array}{c}\text { Normally grown } \\
(n=4)\end{array}$ & $\begin{array}{c}\text { Growth-retarded } \\
(n=4)\end{array}$ & $\begin{array}{c}\text { Significance of } \\
\text { difference }(P)\end{array}$ \\
\hline Birth weight $(\mathrm{kg})$ & $4.89 \pm 0.21$ & $2.24 \pm 0.26$ & - \\
Plasma concentration & $2.63 \pm 0.95$ & $1.42 \pm 0.23$ & n.s. \\
Glucose $\left(\left.\mathrm{mmol}\right|^{-1}\right)$ & $6.39 \pm 0.32$ & $8.31 \pm 0.25$ & $<0.01$ \\
Urea $\mathrm{N}\left(\mathrm{mmol}^{-1}\right)$ & $0.13 \pm 0.06$ & $0.09 \pm 0.02$ & n.s. \\
Insulin $\left(\mu \mathrm{g} \mathrm{I}^{-1}\right)$ & $10.8 \pm 4.3$ & $49.1 \pm 17.0$ & $<0.05$ \\
Growth hormone $\left(\mu \mathrm{g} \mathrm{I}^{-1}\right)$ & $158 \pm 22$ & $36 \pm 7$ & $<0.001$ \\
IGF-I $\left(\mu \mathrm{g} \mathrm{I}^{-1}\right)$ & $3.8 \pm 0.3$ & $4.1 \pm 0.3$ & n.5. \\
Leptin $\left(\mu \mathrm{g} \mathrm{I}^{-1}\right)$ & & & \\
\hline
\end{tabular}

Values are means \pm SEM.

IGF-I: insulin-like growth factor I; n.s.: not significant.

Data from Ehrhardt et al. (2001) and Greenwood et al. (2002).

ef al. (1998). The duration of gestation of growth-retarded lambs was similar to that for normal lambs. Influences of prenatal growth retardation on aspects of postnatal growth, body composition, tissue development and gene expression were also studied.

\section{Metabolic and endocrine characteristics at birth}

Data for lambs sampled before feeding and within $2 \mathrm{~h}$ of birth are summarized (Table 1 ). The moderately high plasma concentrations of urea nitrogen in growth-retarded lambs could have been due to greater rates of amino acid catabolism or lower capacity for renal clearance of urea, both of which are fetal characteristics and might be regarded as signs of immaturity. The small lambs also tended to be more hypoglycaemic than lambs of normal birth weight, possibly extending from the chronic hypoglycaemia that is typical of late-gestation fetuses that experience placental insufficiency (Bell et al., 1999). However, the most striking feature of these observations is the apparent immaturity of the somatotrophic axis in the growthretarded lambs, which is indicated by very high concentrations of growth hormone $(\mathrm{GH})$ and low concentrations of insulin-like growth factor I (IGF-I) that are more reminiscent of the late gestation fetus than of the normal, well-grown lamb immediately after birth (Gluckman et al., 1999). It is notable that hepatic expression of the gene for the acid-labile subunit (ALS), which is $\mathrm{GH}$ dependent and is greatly increased at or soon after birth in normal lambs (Rhoads et al., 2000a), was reduced in naturally growth-retarded newborn lambs from prolific ewes (Rhoads et al., 2000b). An early postnatal reduction in the hepatic synthesis and secretion of ALS would delay the normal postnatal shift in size of circulating IGF complexes from $50 \mathrm{kDa}$ to $150 \mathrm{kDa}$ (Butler and Gluckman, 1986) and the consequent major increases in half-life and concentration of circulating IGF-I. Other indices of hepatic GH responsiveness, including expression of mRNA for the GH receptor, IGF-I and IGF-binding protein (IGFBP)-3 were not significantly affected by birth weight (Rhoads et al., 2000b).

It is notable that reduced hepatic expression of both ALS and IGF-I was discernible as early as day 130 of gestation in growth-retarded fetuses, despite the much lower absolute expression of these genes in fetal versus neonatal lambs (Rhoads et al., 2000b). These data are consistent with decreases in fetal plasma IGF-I that were highly correlated with decreases in placental weight and apparent delivery of glucose and oxygen in carunclectomized ewes during late pregnancy (Owens et al., 1994), given that, in both cases, fetal growth retardation 


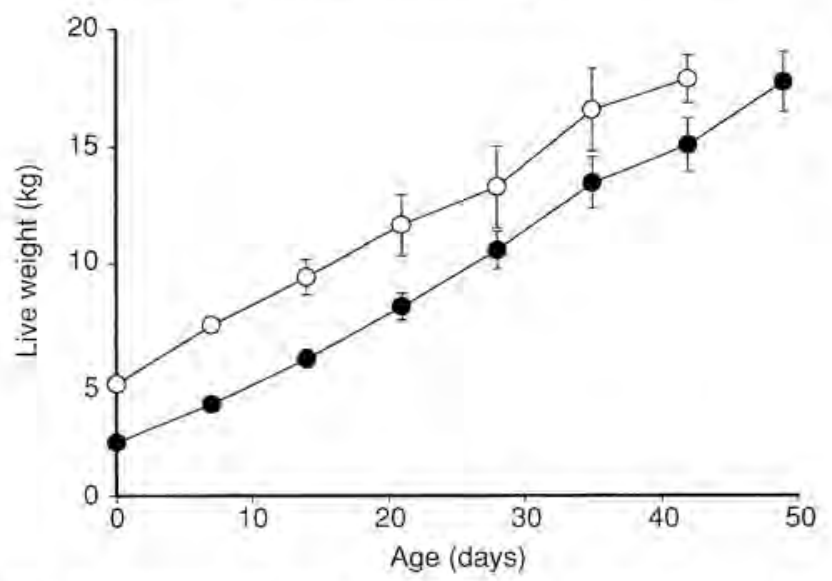

Fig. 2. Growth of low $(-n=16)$ and normal $(0, n=12)$ birth weight lambs that were artificially reared from birth to approximately $20 \mathrm{~kg}$ live weight and had unlimited access to a high quality milk replacer. Values are means \pm SEM for birth weight and weekly measurements of live weight (data from Greenwood et al., 1998).

was due to placental insufficiency. The endocrine mediation of altered development of the GH-IGF system is unclear. A logical candidate for this role might be cortisol, the plasma concentration of which is increased in the placentally retarded fetus (Phillips et al., 1996). However, treatment with cortisol appears to advance, rather than retard, the development of $\mathrm{GH}$-dependent hepatic expression of IGF-I in the late gestation sheep fetus (Fowden et al., 1998).

Plasma leptin concentrations were similarly low in small and normally grown newborn lambs (Table 1) (Ehrhardt et al., 2001), consistent with their low and similar relative masses of adipose tissue and total body lipid (Greenwood et al., 1998).

\section{Postnatal growth and tissue development}

Whole-body growth and composition. Artificially reared, growth-retarded lambs born to prolific ewes grew more slowly than normal lambs, in absolute terms, during the first 2 weeks of postnatal life, despite higher relative rates of gain. However, thereafter, their absolute growth rales to $20 \mathrm{~kg}$ live weight almost exactly matched those of the normal birth weight lambs when both groups were fed unlimited amounts of a high quality milk replacer (Fig. 2) (Greenwood et al., 1998). Thus, it appears that when maternal, social and nutritional, and environmental disadvantages (Mellor, 1988) are minimized, neonatal growth potential is little affected by prenatal growth restriction per se.

Low birth weight lambs were somewhat fatter than normal birth weight lambs at all stages of postnatal growth up to $20 \mathrm{~kg}$ body weight. Their propensity for greater rates of fat deposition was most obvious during the first 2 weeks after parturition and apparently related to rapid relative rates of energy intake, lower maintenance energy requirements and limited capacity for lean growth (Greenwood et al., 1998). Increased fat content at any given body weight in low birth weight lambs was offset more by reduction in ash content than in protein content, indicating that bone was more limited than lean soft tissues in its capacity to respond to the rapid increase in nutrient supply after birth. These early responses may contribute to the 


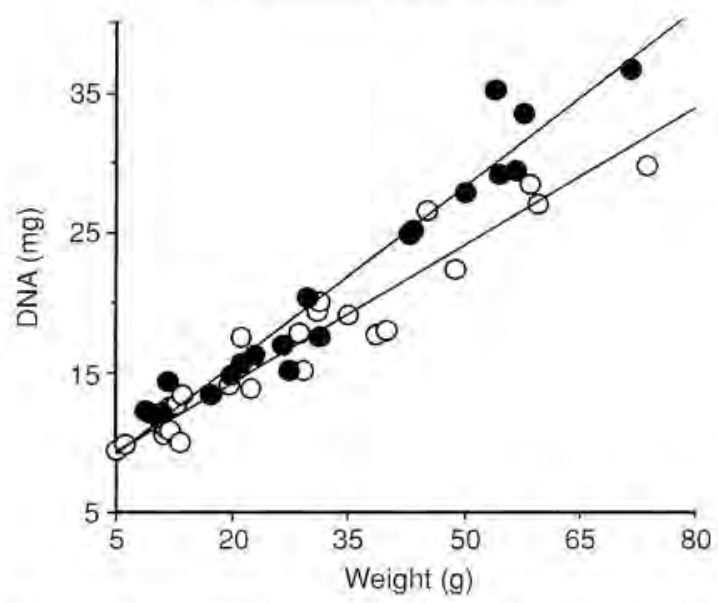

Fig. 3. Total DNA (mg) in semitendinosus muscle of low $(0, n=28)$ and high $(\bullet, n=20)$ birth weight lambs that were reared from birth to a live weight of approximately $20 \mathrm{~kg}$ (data from Greenwood et al., 2000b),

smaller mature size of sheep born to ewes that are severely undernourished during pregnancy (Schinckel and Short, 1961; Everitt, 1967).

Tissue growth and functional development. Effects of IUGR on postnatal relative growth of organs and tissues were assessed by comparing lambs of normal and low birth weight at common empty body weights (live weight minus gut contents) during growth to approximately $20 \mathrm{~kg}$ live weight. At any given empty body weight, low birth weight male lambs had a larger spleen and testes and a greater total visceral mass than normal birth weight lambs (P. Greenwood and A. Bell, unpublished). Conversely, the rates of gain in several skeletal muscles, including the semitendinosus, were persistently slower in low birth weight lambs, as were rates of gain in DNA, RNA and protein in the semitendinosus muscle (Greenwood et al., 2000b). In addition, at any given weight during postnatal growth, the semitendinosus muscle contained less DNA (Fig. 3). This finding indicates that although myofibre number per anatomical muscle is unaffected by IUGR (Greenwood et al., 1999, 2000b), the capacity for postnatal growth of muscle is constrained by decreased mitotic rates of fetal myosatellite cells during late gestation (Greenwood et al., 1999) and low muscle DNA content at birth (Greenwood et al., 2000b).

Growth-retarded newborn lambs tended to have shorter and sparser coats at birth than normal lambs, due to the failure of secondary skin follicles to mature and produce wool fibres during late gestation (Alexander, 1974). This failure could lead to a lifelong penalty in capacity for wool growth, as observed in growth-retarded lambs born to severely undernourished ewes (Schinckel and Short, 1961).

Consistent with other signs of apparent immaturity at birth, growth-retarded lambs experienced more digestive dysfunction and were harder to train to suck than normally grown lambs during the first few days after birth. Although digestive capacity was not measured objectively, our subjective observations are consistent with reports of decreased digestibility of milk replacer in low birth weight lambs (Houssin and Davicco, 1979) and impaired intestinal development in the growth-retarded ovine fetus (Avila et al., 1989). The attainment of 
Table 2. Plasma concentrations of metabolites and hormones in lambs of normal and low birth weight during early ( $<2$ weeks) and later ( $2-8$ weeks) neonatal life

\begin{tabular}{|c|c|c|c|c|}
\hline \multirow[b]{2}{*}{ Plasma concentration } & \multicolumn{2}{|c|}{ Age $<2$ weeks $^{a}$} & \multicolumn{2}{|c|}{ Age 2-8 weeks ${ }^{b}$} \\
\hline & $\begin{array}{c}\text { Normal } \\
\text { birth weight } \\
(n=10)\end{array}$ & $\begin{array}{c}\text { Low birth } \\
\text { weight } \\
(n=10)\end{array}$ & $\begin{array}{c}\text { Normal } \\
\text { birth weight } \\
(n=6)\end{array}$ & $\begin{array}{c}\text { Low birth } \\
\text { weight } \\
(n=6)\end{array}$ \\
\hline Glucose $\left(\mathrm{mmol} \mathrm{I}^{-1}\right)$ & 6.8 & 7.5 & 7.3 & 7.2 \\
\hline Urea $N\left(\mathrm{mmol}^{-1}\right)$ & 5.7 & 3.9 & 5.6 & 5.2 \\
\hline Insulin $\left(\left.\mu \mathrm{g}\right|^{-1}\right)$ & 2.5 & 1.7 & 3.1 & $4.2^{*}$ \\
\hline Growth hormone $\left(\left.\mu g\right|^{-1}\right)$ & 3.2 & $7.0^{*}$ & 4.8 & 5.2 \\
\hline $\mid G F-I\left(\left.\mu g\right|^{-1}\right)$ & 559 & $400^{*}$ & 480 & $616^{*}$ \\
\hline Leptin $\left(\mu \mathrm{gl}^{-1}\right)$ & 4.6 & 4.3 & 5.9 & 5.8 \\
\hline
\end{tabular}

Values are means of measurements taken at days $5,7,9,11$ and 13 after birth.

"Values are means of five or six weekly measurements taken at 2-7 weeks of age; weekly samples were pooled from individual samples taken several times each week.

Data from Greenwood et al. (1998), Ehrhardt et al. (2001) and Greenwood et al. (2002).

- Significantly different from mean value for normal birth weight lambs within the same age group $(P<0.05)$,

IGF-I: insulin-like growth factor I.

aggressive feeding behaviour and very high intakes of milk replacer by small lambs within a week of birth indicates that the nutritional consequences of perinatal gastrointestinal immaturity are short-lived. Certainly, the mass of stomach, small and large intestines, separately and in aggregate, was unaffected by birth size at any given empty body weight during rearing to $20 \mathrm{~kg}$ live weight (P. Greenwood and A. Bell, unpublished).

The functional consequences of the relatively rapid postnatal growth of spleen and testes, and constraint of muscle growth in low birth weight lambs remain to be investigated. It is notable that testicular volume increased more slowly and puberty was delayed in growthretarded ram lambs born to overfed adolescent ewes compared with lambs of normal birth weight (Da Silva et al., 2001).

\section{Postnatal metabolic and physiological development}

Most of the data discussed in this section, dealing with effects of size at birth on plasma concentrations of metabolites and hormones in neonatal lambs, are summarized (Table 2) and described in detail elsewhere (Greenwood et al., 2002). Postnatal changes in superficial indices of carbohydrate and protein metabolism were little affected by birth weight in small and normal lambs that were artificially reared with ad libitum access to milk replacer. The very high concentrations of plasma $\mathrm{GH}$ in small, newborn lambs decreased markedly within 2 days of birth but remained significantly higher than concentrations in lambs of normal birth weight for about 2 weeks. During the same period, plasma IGF-I increased steadily in both groups but remained significantly lower in the small lambs (Greenwood et al., 2002). These observations imply that the apparent immaturity of the GH-IGF axis in growth-retarded newborn lambs. persists for several weeks after birth. Only during this early postnatal phase did the absolute growth rates of low birth weight lambs ( $248 \mathrm{~g}$ per day) lag significantly behind those of normal birth weight lambs (353 g per day) (Greenwood et al., 1998). Thereafter, during rapid growth from about 2 weeks of age to slaughter at $20 \mathrm{~kg}$ (attained at $6.5-8.0$ weeks of age), plasma IGF-I concentrations were persistently higher but $\mathrm{GH}$ concentrations were not different in low versus normal birth weight lambs (Table 2). This study did not examine the consequences of low birth weight after weaning. However, plasma GH concentrations tended to be higher 
during adolescence (approximately 132 days of age) and adulthood (approximately 378 days of age) in low birth weight male lambs from carunclectomized ewes compared with lambs of normal birth weight and were negatively correlated with indices of birth size (Gatford et al., 2002).

Plasma insulin concentrations increased rapidly during the early postnatal period in small lambs feeding ad libitum, consistent with their very high energy intake. From about 2 weeks of age until slaughter at $20 \mathrm{~kg}$, plasma insulin concentrations were persistently higher in low compared with normal birth weight lambs (Table 2). It is possible that this relative hyperinsulinaemia is due to the predisposition of growth-retarded neonates to develop insulin resistance (Hales et al., 1996).

The relatively rapid rates of fat deposition in low birth weight lambs feeding ad libitum were accompanied by significantly higher plasma concentrations of leptin during week 1 after birth, but not thereafter (Ehrhardt et al., 2001).

\section{Fetal programming of postnatal pathophysiology}

\section{Effects of IUGR}

The epidemiological evidence for fetal programming in humans has implicated IUGR as an important risk factor for mature onset of diseases including hypertension and type II diabetes (Barker, 1998). These associations have been replicated in rodent models, usually involving maternal protein restriction (Langley-Evans, 2001) and, to a limited extent, in various models of IUGR in sheep (McMillen et al., 2001). Consistent with some clinical observations on small for dates babies, low birth weight lambs from ewes subjected to placental embolization (Louey et al., 2000) or glucocorticoid treatment (Moss et al., 2001) during late pregnancy were relatively hypotensive during the first $2-3$ months of postnatal life. However, McMillen et al. (2001) have cited their own preliminary evidence that by 1 year of age, systolic blood pressure was inversely related to indices of birth size in normal and placentally restricted lambs from carunclectomized ewes. The authors suggest that this long-term response may involve cortisol-induced fetal sensitization of the vasoconstrictor response to angiotensin II, based on observations of increased cortisol secretion (Phillips et al., 1996) and vascular responsiveness to angiotensin (Edwards et al., 1999) in the placentally retarded sheep fetus, and of the direct effects of cortisol infusion on fetal blood pressure and vascular responses to angiotensin 11 (Tangalakis et al., 1992). During placental insufficiency, these effects may be exacerbated through downregulation of placental activity of $11 \beta$-hydroxysteroid dehydrogenase type 2 (11 3 HSD2) by increased fetal cortisol secretion, thereby increasing exposure of the fetus to maternal cortisol (Clarke et al., 2002). Putative mechanistic links between maternal nutrition, placental function, fetal cortisol status, and developmental consequences are outlined schematically (Fig. 4).

Persuasive evidence that prenatal growth retardation leads to postnatal development of insulin resistance in ruminants has yet to be obtained. Glucose and insulin tolerance at 1,3 and 6 months of age were unimpaired in twin lambs that were approximately $20 \%$ lighter than their co-twins at birth (Clarke et al., 2000). However, this growth penalty may have been insufficient to elicit an effect because even the lighter twins were relatively large (approximately $4 \mathrm{~kg}$ ) at birth. The persistent relative hyperinsulinaemia of more severely growth-retarded lambs during growth to $20 \mathrm{~kg}$ (Table 2; Greenwood et al., 2002) is indicative of insulin resistance as a postnatal consequence of IUGR.

In addition to its putative long-term effects on cardiovascular pathophysiology, increased exposure to cortisol in growth-retarded fetuses could also influence the development of insulin 


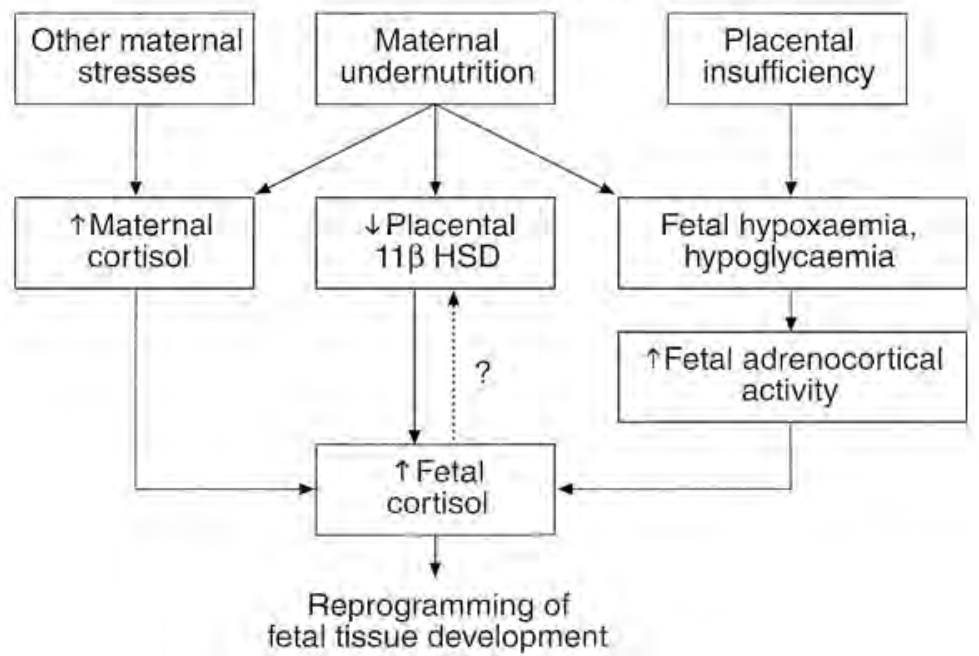

Fig. 4. Schematic diagram showing how fetal plasma cortisol concentrations in sheep are increased by conditions associated with intra-uterine growth retardation that are believed to exert effects on reprogramming of fetal tissue development (modified from Fowden et al., 1998).

resistance in the liver and peripheral tissues, and have implications for postnatal metabolic health (Fig. 4). Plasma concentration of cortisol was increased in placentally restricted sheep fetuses during late gestation (Phillips et al., 1996). In addition, hepatic exposure may be increased locally by upregulation of the capacity of the liver to convert cortisone to cortisol, consistent with the observation of increased expression of 11BHSD1 in liver of placentally retarded fetuses (McMillen et al., 2000). In the only published study on postnatal consequences of fetal overexposure to cortisol in sheep, treatment of lamb fetuses with betamethasone during late pregnancy caused increased insulin responses to glucose challenges with no effect on glycaemic responses at 6 and 12 months of postnatal age (Moss et al., 2001). These animals also displayed altered responsiveness of the hypothalamic-pituitary-adrenal axis at 12 months but not 6 months of age, in ways that varied according to the timing of prenatal glucorticoid treatment, and whether it was administered to the dam or fetus (Sloboda et al., 2002).

\section{Effects of maternal nutrition and other factors during early pregnancy}

Growing evidence from studies on sheep and other species indicates that fetal programming can involve long-term sequelae to changes in the early prenatal environment that do not necessarily cause changes in gross morphology of the fetus. For example, modest undernutrition of ewes during the first half of pregnancy had no effect on growth of lambs during fetal or postnatal life but caused relative hypertension and increased activity of the HPA axis in lambs aged 12-13 weeks (Hawkins et al., 2000). Consistent with these responses, maternal undernutrition between early and mid-gestation caused increased expression of the glucocorticoid receptor in adrenal gland, kidney, liver, lungs and perirenal adipose tissue of the fetus at term (approximately 145 days) (Whorwood et al., 2001). At the same time, there was increased expression of 11BHSD1 in perirenal adipose tissue (but not in other tissues), marked decreases in expression of 11BHSD2 in the adrenal gland and kidney, and 
increased expression of glucocorticoid-responsive angiotensin II type 1 receptor in tissues in which increased expression of the glucocorticoid receptor and/or decreased expression of $11 \beta$ HSD1 was observed. Some of these tissue-specific fetal responses were evident as early as day 77 of gestation.

A central role for corticosteroids in the mediation of fetal programming was further implicated by the surprising finding that exposure of ewes to high doses of dexamethasone for only 2 days in early pregnancy resulted in hypertensive offspring at 3-4 months of age (Dodic et al., 1998). This hypertension amplified with age to beyond three years and was associated with increased cardiac output (Dodic et al., 1999) but no change in responsiveness of the HPA axis (Dodic et al., 2002). Glucose metabolic responses to insulin were unaltered but the ability of insulin to suppress net fatty acid release from adipose tissue (plasma non-esterified fatty acid concentration) was moderately enhanced (Gatford et al., 2000).

\section{Conclusions}

The problem of low birth weight in domestic ruminants, especially sheep, has long been appreciated in terms of perinatal mortality related to the diminished capacity of small neonates to withstand themoregulatory and nutritional challenges soon after birth (Alexander, 1974). Negative consequences for postnatal growth and productivity of surviving small neonates have also been documented (Bell, 1992). During the past decade, a new awareness of the possible long-term effects of nutritional insults during fetal life has grown out of landmark research on epidemiological associations between birth size and incidence of mature-onset diseases in humans (Barker, 1998). The sheep offers an excellent biomedical model for investigation of the underlying mechanisms of fetal programming because of its amenability to experimental manipulation during fetal and postnatal life and its combination of a relatively long gestation period with rapid postnatal maturation. It is certain that such investigations will also lead to a new understanding of the influence of prenatal experience on postnatal development of key tissues and functions important to animal productivity, including muscle growth, reproduction, lactation and disease resistance.

\section{References}

Alexander G (1964) Studies of the placenta of the sheep (Ovis aries L.): effect of surgical reduction in the number of caruncles Journal of Reproduction and Fertility 7 307-322

Alexander G (1974) Birth weight of lambs: influences and consequences, In Size at Birth pp 213-239 Eds KElliott and I Knight. Elsevier, Amsterdarn

Alexander G and Williams D (1971) Heat stress and development of the conceptus in domestic sheep Journal of Agricultural Science, Cambridge 76 $53-72$

Avila CG, Harding R, Rees S and Robinson PM (1989) Small intestinal development in growth-retarded fetal sheep Journal of Pediatric Gastroenterology and Nutrition 8 507-515

Barker DJP (1998) Mothers, Babies and Health in Later Life 2nd Edn. Churchill Livingstone, Edinburgh

Bell AW (1992) Foetal growth and its influence on postnatal growth and development. In The Control of Fat and Lean Deposition pp 111-127 Eds PJ Butlery, KN
Boorman and DB Lindsay: Butterworth-Heinemann, Oxford

Bell AW, Wilkening RB and Meschia G (1987) Some aspects of placental function in chronically heatstressed ewes Journal of Developmental Physiology $917-29$

Bell AW, Hay WW, Jr and Ehrhardt RA (1999) Placentaltransport of nutrients and its implications for fetal growth Journal of Reproduction and Fertility Supplement 54 401-410

Butler JH and Gluckman PD (1986) Circulating insulinlike growth factor-binding proteins in fetal, neonatal and adult sheep Journal of Endocrinology 109 333-338

Clarke L, Firth K, Heasman L, Juniper DT, Budge H, Stephenson T and Symonds ME (2000) Influence of size at birth on growth and glucose homeustasis in twin lambs during juvenile life Reproduction, Fertility and Development 12 69-73 
Clarke KA, Ward JW, Forhead AJ, Giussani DA and Fowden AL (2002) Regulation of $11 \beta$-hydroxysteroid dehydrogenase type 2 activity in ovine placenta by fetal cortisol Journal of Endocrinology 172 527-534

Creasy RK, Barrett CT, De Swiet M, Kahanpää KV and Rudolph AM (1972) Experimental intrauterine growth retardation in the sheep American Journal of Obstetrics and Gynecology 112 566-573

Da Silva P, Aitken RP, Rhind SM, Racey PA and Wallace JM (2001) Influence of placentally mediated fetal growth restriction on the onset of puberty in male and female lambs Reproduction $\mathbf{1 2 2}$ 375-383

Dodic M, May CN, Wintour EM and Coghlan JP (1998) An early exposure to excéss glucocorticoid leads tó hypertensive offspring in sheep Clinical Science $\mathbf{9 4}$ 149-155

Dodic M, Peers A, Coghlan JP, May CN, Lumbers E, Yu Z-Y and Wintour EM (1999) Altered cardiovascular haemodynamics and baroreceptor-heart rate reflex in adult sheep after prenatal exposure to dexamethasone Clinical Science 97 103-109

Dodic M, Peers A, Moritz K, Hantzis V and Wintour EM (2002) No evidence for HPA reset in adult sheep with high blood pressure due to short prenatal exposure to dexamethasone American Journal of Physiology 282 R343-R350

Edwards LJ, Simonetta G, Owens JA, Robinson IS and McMillen IC (1999) Restriction of placental and fetal growth in sheep alters fetal blood pressure responses. to angiotensin II and captopril Journal of Physiology 515 897-904

Ehrhardt RA, Greenwood PL, Slepetis RM, Bell AW and Boisclair YR (2001) Postnatal nutrition and fatness affect plasma leptin concentration in neonatal sheep Journal of Animal Science 79 Supplement 1225

Everitt GC (1967) Residual effects of prenatal nutrition on the postnatal performance of merino sheep Proceedings of the New Zealand Society of Animal Production 27 52-68

Everitt GC (1968) Prenatal development of uniparous animals, with particular reference to the influence of maternal nutrition in sheep. In Growth and Development of Mammals pp 131-157 Eds GA Lodge and GE Lamming. Butterworths, London

Fowden AL, Li J and Forhead AJ (1998) Glucocorticoids and the preparation for life atter birth: are there long-term consequences of the life insurance? Proceedings of the Nutrition Society $\mathbf{5 7}$ $113-122$

Gatford KL, Wintour EM, De Blasio MJ, Owens IA and Dodic M (2000) Differential timing for programming of glucose homeostasis, sensitivity to insulin and blood pressure by in utero exposure to dexamethasone in sheep Clinical Science $\mathbf{9 8}$ $553-560$
Gatford KL, Clarke IJ, De Blasio MJ, McMillen IC, Robinson JS and Owens JA (2002) Perinatal growth and plasma $\mathrm{GH}$ profiles in adolescent and adult sheep Journal of Endocrinology 173 151-159

Gluckman PD, Sizonenko SV and Bassett NS (1999) The transition from fetus to neonate: an endocrine perspective Acta Paediatrica Supplement $\mathbf{4 2 8}$ 7 -11

Greenwood PL, Hunt AS, Hermanson JW and Bell AW (1998) Effects of birth weight and postnatal nutrition on neonatal sheep. I. Body growth and composition, and some aspects of energetic efficiency Journal of Animal Science 76 2354-2367

Greenwood PL, Slepetis RM, Hermanson JW and Bell AW (1999) Intrauterine growth retardation is associated with reduced cell cycle activity, but not myofibre number, in ovine fetal muscle Reproduction, Fertility and Development 11 281-291

Greenwood PL, Slepetis RM and Bell AW (2000a) Iniluences on fetal and placental weights during mid-and late gestation in prolific ewes well nourished throughout pregnancy Reproduction, Fertility and Development 12 149-156

Greenwood PL, Hunt AS, Hermanson JW and Bell AW (2000b) Effects of birth weight and postnatal nutrition on neonatal sheep. 11. Skeletal muscle growth and development Journal of Animal Science 78 $50-61$

Greenwood PL, Hunt AS, Slepetis RM, Finnerty KD, Alston C, Beermann DH and Bell AW (2002) Effects of birth weight and postnatal nutrition on neonatal sheep. III. Regulation of energy metabolism Journal of Animal Science $\mathbf{8 0}$ 2850-2861

Hales CN, Desai M, Ozanne SE and Crowther NJ (1996) Fishing in the stream of diabetes: control of fetal organogenesis Biochemical Society Transactions 24 $341-350$

Harding JE, Jones CT and Robinson JS (1985) Studies on experimental growth retardation in sheep. The effects of a small placenta in restricting transport to and growth of the fetus Journal of Developmental Physiology 7 427-442

Hawkins P, Steyn C, McGarrigle HHG, Calder NA, Saito T, Stratford LL, Noakes DE and Hanson MA (2000) Cardiovascular and hypothalamic-pituitary axis development in late gestation fetal sheep and young lambs following modest maternal nutrient restriction in early gestation Reproduction, Fertility and Development 12 443-456

Houssin Y and Davicco MJ (1979) Influence of birthweight on the digestibility of a milk-replacer in newborn-lambs Annales Recherches Veterinaires 10 419-421

Langley-Evans SC (2001) Fetal programming of cardiovascular function through exposure to maternal undernutrition Proceedings of the Nutrition Society $60505-513$ 
Louey S, Cock ML, Stevenson KM and Harding R (2000) Placental insufficiency and fetal growth restriction lead to postnatal hypotension and altered postnatal growth in sheep Pediatric Research $\mathbf{4 8}$ $808-814$

McMillen IC, Warnes KE, Adams MB, Robinson IS, Owens JA and Coulter Cl (2000) Impact of restriction of placental and fetal growth on expression of $11 \beta$-hydroxysteroid dehydrogenase type 1 and type 2 messenger ribonucleic acid in the liver, kidney and adrenal of the sheep fetus. Endocrinology 141 539-543

McMillen IC, Adams MB, Ross IT, Coulter CL, Simonetta G, Owens JA, Robinson IS and Edwards L) (2001) Fetal growth restriction: adaptations and consequences Reproduction 122 195-204

McNeill DM, Slepetis R, Ehrhardt RA, Smith DM and Bell AW (1997) Protein requirements of sheep in late pregnancy: partitioning of nitrogen between gravid uterus and maternal tissues Journal of Animal Science $75809-816$

Mellor DJ (1983) Nutritional and placental determinants of foetal growth rate in sheep and consequences for the newborn lamb British Veterinary Journal 139 $307-324$

Mellor DJ (1988) Integration of perinatal events, pathophysiological changes and consequences for the newborn lamb British Veterinary Journal 144 552-569

Moss TJM, Sloboda DM, Gurrin LC, Harding R, Challis JRG and Newnham JP (2001) Programming effects in sheep of prenatal growth restriction and glucocorticoid exposure American lournal of Physiology 281 R960-R970

Owens JA, Falconer J and Robinson JS (1986) Effect of restriction of placental growth on umbilical and uterine blood flows American Journal of Physiology $\mathbf{2 5 0}$ R427-R434

Owens JA, Kind KL, Carbone F, Robinson JS and Owens PC (1994) Circulating insulin-like growth factors-1 and -11 and substrates in fetal sheep following restriction of placental growth Journal of Endocrinology $1405-13$

Phillips ID, Simonetta G, Owens JA, Robinson JS, Clarke I) and McMillen IC (1996) Placental restriction alters the functional development of the pituitary-adrenal axis in the sheep fetus during late gestation Pediatric Research $\mathbf{4 0} 861-866$
Rhind SM, Robinson If and McDonald I (1980) Relationships among uterine and placental factors in prolific ewes and their relevance to variations in foetal weight Animal Production 30 115-124

Rhoads RP, Greenwood PL, Bell AW and Boisclair YR (2000a) Organization and regulation of the gene encoding the sheep acid-labile subunit of the $150 \mathrm{kDa}$-binding protein complex Endocrinology 141 1425-1433

Rhoads RP, Greenwood PL, Bell AW and Boisclair YR (2000b) Nutritional regulation of the genes encoding the acid-labile subunit and other components of the circulating insulin-like growth factor system in the sheep Journal of Animal Science 78 2681-2689

Schinckel PG and Short BF (1961) The influence of nutritional level during pre-natal and early postnatal life on aduit fleece and body characteristics Australian Journal of Agricultural Research 12 176-202

Sloboda DM, Moss TI, Gurrin LC, Newnham IP and Challis JRG (2002) The effect of prenatal betamethasone administration on postnatal ovine hypothalamic-pituitary-adrenal function Journal of Endocrinology 172 71-81

Tangalakis K, Lumbers E, Moritz KM, Towstoless MK and Wintour EM (1992) Effect of cortisol on blood pressure and vascular reactivity in the ovine fetus Experimental Physiology $77709-717$

Wallace JM, Bourke DA, Aitken RP, Palmer RM, Da Silva and Cruickshank MA (2000) Relationship between nutritionally-mediated placental growth restriction and fetal growth, body composition and endocrine status in adolescent sheep Placenta 21 100-108

Wallace LR (1948) The growth of lambs before and after birth in relation to the level of nutrition Journal of Agricultural Science, Cambridge 38 367-401

Wallace JM, Bourke DA, Aitken RP, Leitch N and Hay WW, Jr (2002) Blood flows and nutrient uptakes in growth-restricted pregnancies induced by overnourishing adolescent sheep American journal of Physiology 282 R1027-R1036

Whorwood CB, Firth KM, Budge $\mathrm{H}$ and Symonds ME (2001) Maternal undernutrition during early to mid-gestation programs tissue-specific alterations in the expression of the glucocorticoid receptor, $11 \beta$-hydroxysteroid dehydrogenase isoforms, and type 1 angiotensin II receptor in neonatal sheep Endocrinology $1422854-2864$ 